\title{
Strengthen Government Purchase Management
}

\author{
Chao Wang
}

Shanxi University of Finance and Economics, Taiyuan, 030006, China

\author{
Keywords: Government purchase. Management
}

\begin{abstract}
The government purchase course of Anyang High-tech Zone Management Committee is reviewed, the characteristics of government purchase of Anyang High-tech Zone Management Committee are summarized and some problems exiting in the government purchase management of Anyang High-tech Zone Management Committee are revealed. In order to solve the existing problems, by reference to the model in the surrounding areas of Anyang, a public resource transaction center is established for central management and a government purchase committee is set up to regulate the government purchase, enhance supervision and strengthen regulation.
\end{abstract}

\section{Concept and objective of government purchase}

Government purchase means the behavior that the national authorities, institutions and organizations at each level use the financial funds to purchase the goods, engineering and service within the central purchase category established according to the law or those above the purchase quota standard. The government purchase does not only refer to the specific purchase process, but is also the collection of purchase policy, procedure, process and management, being a system for the public purchase management and a government behavior. In such behavior, the following subjects are contained, namely purchaser, government purchase institution, bid agency and supplier, in which the government purchase institution means the special institution established by the government to be responsible for the central purchase and bid organization work of financial fund at the designated level. There are mainly three modes of government purchase, namely central purchase mode, i.e. a special government purchase institution is responsible for all purchase tasks of he designated level; scattered purchase mode, i.e. the each purchase expending institution carries out purchase at its own discretion and semi-central and semi-scattered purchase mode, i.e. the special government purchase institution is responsible for the purchase of some projects, while others are the responsibility of each unit itself.

The main objectives of government purchase include (1) objective of economic effectiveness, i.e. to save and reasonable use the financial funds, and purchase the goods, engineering and services with quality conforming to the requirements with the most favorable price etc., making the performance and price ratio of the goods, engineering and services optimal. Government of each country takes the economic effectiveness of government purchase as the first objective. (2) Market objective, i.e. to promote the marketization of government consumption behavior, encourage honest and credible commercial behavior, promote competition and guide the consumers' behaviors. (3) Policy objective. The policy objective is that the government hopes to the specific objective of social and economic policy by virtue of the purchase system.

\section{Formation and management of government purchase of Anyang High-tech Zone}

\section{Development of government purchase in Anyang High-tech Zone}

The Purchase Office of Anyang High-tech Industrial Development Zone Control Group was established in 1996, through more than 10 years' development, the purchase business has been developed from the initial purchase of government office articles to the purchase of goods, engineering and services etc. In 2011, the purchase office organized 77 bid purchases, with purchase budget amount RMB 12336037.00, actual purchase amount 8760532.82 and RMB 3575504.18 was waved, with a saving rate of $28.98 \%$. In the first half of 2012, 35 government purchases were 
completed, with purchase budget amount RMB 21732670.00, actual purchase amount RMB 18388349.21, and RMB 3344320.79 was saved, with an average saving rate of $15 \%$, and up to $49.7 \%$ for some project funds. In the first half of 2013, 24 purchases were completed, with a purchase budget amount of RMB 3875600.00, actual purchase amount 3207035, and RMB 668565.00 was saved, with an average saving rate of $17.25 \%$ and up to $29.17 \%$ for some project funds.

All purchase management functions of the local government are undertaken by the financial department, and there is institution of administrative management function set or made clear accordingly. According to the purchase setting mode of Anyang Municipal Government, the Anyang High-tech Industrial Development Zone Financial Bureau under the Purchase Office of Anyang High-tech Industrial Development Zone Control Group is the first-level unit under the Financial Bureau, responsible for the central purchase and bid organization work of Anyang High-tech Zone financial fund. The High-tech Zone Financial and Tax Audit Bureau supervises the financial funds, approval direction and purchase procedure of the purchase. The discipline inspection work committee of the High-tech Zone supervises the bid invitation document and bid opening process.

\section{Characteristics of government purchase system of Anyang High-tech Zone}

The purchase scope is expanding continuously, extending to goods, engineering and services

The government purchase of Anyang High-tech Management Committee took the office equipment as the main purchase target originally, and later extended to such fields as goods, engineering and services. Since 2010, the government purchase work was focused on the expansion of purchase and scope, by taking effective measures, new breakthrough has been made in goods, engineering and service purchase. At present, the goods are not only involved in automobile, general office equipment, but are also expanded to the flood prevention materials and mark making. The engineering is not only limited to road construction, but is also expanded to the greening engineering, school construction and sporadic maintenance.

The purchase mode is increasingly diversified, basically adapting to the demand of government purchase of Anyang High-tech Zone

In recent years, with the continuous perfection of market economy, and the improving of information transparency, and expansion of government purchase scope and the diversification of categories, in order to improve the government purchase efficiency and effectively save funds, Purchase Office of Anyang High-tech Industrial Development Zone Control Group adopts the mode of central purchase and public bid invitation, including bid invitation, competitive negotiation, low-price bid wining and inquiring etc., which both guarantees the quality of bid invitation and adapts to the demands of the purchaser better.

The deepening of government purchase plays an active role to the social and economic development of the high-tech zone

The saving rate of the financial funds is improving continuously, in 2010, there were 75 government purchases, and RMB 3452665.00 was saved, with a saving rate of 12.29\%; in 2011, 77 government purchases were completed, and RMB 3575504.18 was saved, with a saving rate of $28.98 \%$ and up to $59 \%$ for some project funds. The expansion of bid invitation effectively promotes the participation of various enterprises and drives the local economic development. In the first half of 2012, 35 government purchases were completed, and RMB 3344320.79 was saved, with an average saving rate of $15 \%$,and up to $49.7 \%$ for some project funds; in the first half of 2013, 24 purchases were completed, and RMB 668565.00 was saved, with an average saving rate of $17.25 \%$, and up to $29.17 \%$ for some project funds.

\section{Problems existing in government purchase of Anyang High-tech Zone}

Some achievements have been made in the government purchase of Anyang High-tech Zone Management Committee, but with the deepening of government purchase, some problems have also occurred in the actual work, which are mainly caused by the imperfect government purchase management system and supervision system, mainly reflected in the following:

Imperfect government purchase management system

Anyang High-tech Zone has not formed the three-level management system of government purchase committee establishing policy, deliberating the purchase category and coordinating, 
purchase office responsible for the purchase management and the purchase center implementing the foreign purchase. At present, the work is the responsibility of Purchase Office of Anyang High-tech Industrial Development Zone Control Group, causing that the purchase plan is not strong, without accurate annual purchase budget and unable to form a batch scale; the policy restriction is weak, making the medical equipment, teaching equipment, infrastructure project and political and legal department special supporting facilities not included in the government purchase supervision and management, causing that there exists resistance in the implementation of standard for government purchase category.

\section{Imperfect government purchase and supervision system}

On one hand, as the high-tech zone has not implemented department budget preparation management reform, the purchaser has no government purchase budget and in the government purchase activities, each unit has a frequent purchase of sporadic demand and immediate demand, with a small amount and small scale central purchase scale, causing that it is unable to integrate the purchases and difficult to form a scale effect. It is difficult to prepare the government purchase plan, making it is difficult to from effective restriction in the government purchase system.

On the other hand, the Purchase Office of Anyang High-tech Industrial Development Zone Control Group is both the supervisor and the implementer and manager in the deliberation of government purchase category, bid invitation organization and bid opening process, and the supervision cannot be separated from the implementation and management effectively, causing that there is unclear supervision subject, supervision authorization and supervision content in the government purchase. Meanwhile, the supervision system of government purchase is relatively loose, and there is no special supervision leading group dedicated for the government purchase

\section{Lagged construction of public resource transaction platform}

At present, Anyang High-tech Zone has not formed effective institutions to integrate the public resources in the whole zone. The government purchase, project bid invitation and land transaction are respectively managed by different competent departments, with not unified mutual operation and no separation of management and office, which does not only increase the management cost, but also increases the supervision difficulty.

\section{Insufficient realization to the government purchase work}

Due to habitual thinking and lack of financial expenditure concept, some purchase units cannot actively apply for the government purchase and have the behavior of avoiding the central government purchase such as "acting first and reporting afterwards", to the extent that the purchase is not subject to the government purchase management department, procedures are re-handled after self-purchase and some units partially emphasize the particularity of the project and urgency of time, do not cooperate with the government purchase, do not make declaration in advance, and try bet not to handle the purchase according to the legal methods and procedures of government purchase.

\section{Operation mode of Chinese government purchase}

\section{Set up government purchase management institutions}

The government purchase committee of each level of government are established, mainly responsible for the establishment, modification and implementation supervision of the government purchase regulations and policies and the main responsibilities of the institutions include: to establish the government purchase expenditure policy, issue purchase plan, audit the purchase audit, approve and allocate the purchase amount, establish the purchase regulations and various systems and coordinate the relation with relevant departments.

Set a "government purchase center" specially responsible for the daily government purchase affairs

According to the national condition of China, a special government purchase center (or purchase government company) is established, which is a non-profit legal person, subordinated to each level of government and guided and supervised by the financial department, with the main responsibilities of organizing and managing purchase affairs of the medium and large-sized engineering, goods and 
service of each level of government, uniformly organizing and managing the goods, engineering and service that can be centrally purchased by the administrative institutions; undertaking other various purchases of the purchasing authorities with purchase qualification canceled by the government purchase committee, and filing and supervising the purchase activities of departments or units authorized for scattered purchase.

The relation between the government purchase center and the government management institutions is first-level entrusting agency, and the government purchase center can also accept the entrusting of various departments or units for direct purchase; due to the limitation of the specific purchase commodities (labor service) and engineering technical factors, the centre can also carries out second-level entrusting, for example, to entrust the professional agency for the specific purchase. No matter how long the entrusting chain is, the client and trustee must comply with the principle of government purchase.

The agencies are various purchase firms with the qualification of performing government purchase independently, or other institutions capable of engaging in such business and subject to the qualification audit of government purchase center. Under the premise of accepting the entrusting of the government purchase center, the agencies mainly select the qualified supplier to recommend to the user through bid invitation or other effective competition methods. Meanwhile, they also accept the complaint fed back by the government purchase centre in respect of the quality of commodities (labor services) provided by the supplier or problems existing in relevant indicators specified in the bid, and are responsible for instituting inquires and even proceedings to the arbitration institution against the supplier.

\section{Suggestions to further strengthen the government purchase management}

As Anyang High-tech Zone is upgraded to a national high-tech zone, its functions and management are continuously expanding, and there are more and more opportunities and adjustments faced. At present, Anyang High-tech Zone doe not manage the public resource transition uniformly, with loose government purchase management, lack of restriction and no separation of supervision and management, which influences the utilization of the public resources and financial funds. These problems are generated by the improper management system and supervision system, therefore, it is required to strengthen the management and supervision to public resources and perfect the government functions.

Perfect management system, and establish a unified public resource transaction platform

Establish a government purchase committee, strengthen the establishment of government purchase policy and the deliberation of government purchase category, so as to make the government purchase more effective and reasonable.

The public resource transaction center is the institution responsible for the transaction of public resources and providing consultation and services. In order to regulate the public resource transaction activity in Anyang High-tech Zone, accelerate the establishment and perfection of a transaction mechanism adapting to the market economy, prevent and govern corruption from the source, a unified, transparent and efficient public resource transaction platform is constructed from the source. It is required to integrate the transaction functions of Anyang High-tech Zone Building Management Construction Office, Purchase Office of Anyang High-tech Industrial Development Zone Control Group and land reserves centre, and establish them in the High-tech Public Resource Transaction Center for central and unified management.

\section{Perfection of supervision system}

The supervision and implementation are separated from management, and a complete government purchase supervision system is established. A supervision team composed of the finance and tax audit bureau, inspection office and discipline work committee is established to be specially responsible for the special audit of government purchase and the supervision of supervision process. Meanwhile, strength supervision to the key links, for example, to establish detailed government purchase category, 
prepare comprehensive government purchase plan and supervise the selection of purchase method etc., so as to ensure the objective and fair purchase process.

\section{Improve publicity and education and improve awareness}

The government purchase system is a basic system for the government to strengthen the financial expenditure management in the market economy condition, which cannot only improve the utilization of financial expenditure of China, but can also promote the construction of a clean government. It is required to strengthen the publicity of government purchase purpose, significance and procedure etc. through slogan, training and newspaper column, and improve the awareness of leaders and staff, so as to make the government purchase operate in a reasonable track.

\section{Strengthen education training and improve business}

Expanding the team of high-quality practitioners of government purchase and carrying out professional training to the government purchase personnel as soon as possible will be beneficial for the smooth proceeding and effective implementation of the government purchase activities. Facing the diversification of government purchase, the purchase personnel should not only have professional theoretical quality and business operation ability, but should also have the knowledge in respect of law, public relation and occupational morality, only in this way can the purchase system of local government be regulated effectively.

\section{References}

[1] Du Xinyuan, Thinking on Strengthening Government Purchase Management [J] Urban Construction Theory Research, Issue 30, 2012

[2] Cao Fuguo, Research on Foreign Government Purchase Theory [J], Foreign Social Science, Issue 03, 1998

[3] Zhong Huimin, Strengthen Budget Management of Government Purchase [J], Metallurgical Financial Accounting, Issue 07, 2010. 